\title{
Decamethylruthenocene Hydride and Hydrogen Formation at LiquidlLiquid Interfaces
}

\author{
Lucie Rivier, ${ }^{\dagger}$ T. Jane Stockmann, ${ }^{\dagger, \dagger}$ Manuel A. Méndez, ${ }^{\dagger}$ Micheál D. Scanlon, ${ }^{\dagger, \S}$ Pekka Peljo, ${ }^{\dagger}$ \\ Marcin Opallo," and Hubert H. Girault* ${ }^{\dagger}$
${ }^{\dagger}$ Laboratoire d’Electrochimie Physique et Analytique, Ecole Polytechnique Fédérale de Lausanne (EPFL), Rue de l’Industrie 17, $\mathrm{CH}-1951$ Sion, Switzerland
${ }^{\ddagger}$ Sorbonne Paris Cité, Paris Diderot University, Interfaces, Traitements, Organisation et Dynamique des Systèmes, CNRS-UMR 7086, 15 rue J.-A. Baif, 75013 Paris, France
${ }^{\S}$ Department of Chemistry, the Tyndall National Institute and the Analytical \& Biological Chemistry Research Facility (ABCRF), University College Cork, Cork, Ireland \\ "Institute of Physical Chemistry, Polish Academy of Sciences, ul. Kasprzaka 44/52, 01-224 Warszawa, Poland
}

Supporting Information

\begin{abstract}
The formation and the dissociation of metal hydrides are key steps within the hydrogen evolution reaction (HER) pathway for photochemical water splitting, but also impacts a wide range of other catalytic, industrial, and biochemical reactions. Herein, we describe our recent work studying HER at the interface between two immiscible electrolyte solutions (ITIES), between waterl1,2-dichloroethane. This is a unique platform for evaluating the kinetics/thermodynamics for metallocene hydride formation using decamethylruthenocene. In this approach, an aqueous acid serves as the proton source and is pumped across the ITIES via an externally applied potential or the use of a phase transfer catalyst. Simulated curves developed using COMSOL Multiphysics software and compared to experimental ones, indicate a modified EC' (electrochemical-chemical) mechanism for the decamethylruthenocene

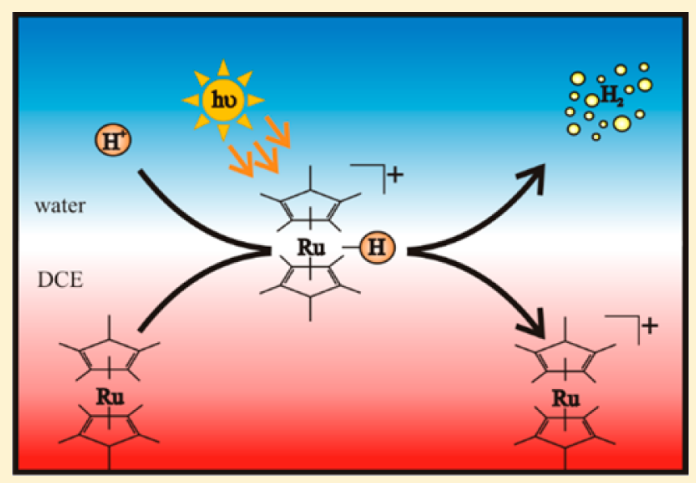
hydride formation. In the proposed pathway, decamethylruthenocene hydride is metastable in 1,2-dichloroethane and persists on the time scale of the recorded cyclic voltammograms long enough to transfer to the aqueous phase where it quickly dissociates. This is evidenced through an asymmetric, ion transfer wave observed experimentally and concluded to be hydride transfer. Shake-flask experiments with head space gas sampling demonstrated that hydrogen production was observed only when the biphasic system was positively polarized, to favor proton transfer, and decamethylruthenocene was photoactivated. This approach, combining electrochemical, simulation, and chromatographic methods, brings new insight into the factors that underlie the mechanism and rates of hydride formation/dissociation at soft interfaces.
\end{abstract}

\section{INTRODUCTION}

Transition metals are possessed of remarkable chemical properties such as multiple valencies, various coordination sites and a number of possible complex structures. ${ }^{1}$ As a consequence, they can be employed as catalysts owing to their exceptional and versatile reactivity and are capable of performing a wide range of chemical and biochemical reactions including hydrogenation, ${ }^{2,3}$ catalysis reduction, ${ }^{4-6}$ and water dissociation. ${ }^{7}$ Catalysts incorporating the transition metal ruthenium at their core have been found to be very effective owing to ruthenium's eight oxidation states, its exceptional functional group tolerance, and its reasonable price relative to architecturally similar noble metal catalysts. ${ }^{8,9}$ Many organoruthenium catalyzed pathways have been explored and are well characterized, and they often involve the formation of a transition metal hydride as an intermediate. ${ }^{9}$ Metal hydrides are crucial steps that allow for the transfer of a free proton to an organic molecule, such as for hydrogenation or hydroformylation. ${ }^{10}$ The understanding and the control of proton transfer, and possibly proton coupled electron transfer, to and from the metal hydride is particularly important in photochemical water splitting $^{11}$ and fuel cell electrocatalysis. ${ }^{12}$

Indeed, with rising energy demands, the depletion of fossil fuel reserves, as well as the resultant anthropogenic climate change owing to the use of carbon based fuels, society is on the cusp of a significant shift toward renewable energy sources. ${ }^{13}$ Organo-metallic catalysis is staged to play a key role to facilitate this change. Among future energy sources under consideration, molecular hydrogen $\left(\mathrm{H}_{2}\right)$ appears very attractive as the only waste from burning $\mathrm{H}_{2}$ in air is water. ${ }^{14}$ Nevertheless,

Received: September 2, 2015

Revised: October 20, 2015

Published: November 5, 2015 
$\mathrm{H}_{2}$ production induces environmental impacts through the tremendous energy required for water electrolysis, ${ }^{4}$ a chief source of protons, and thus, it remains very expensive to produce owing to current methods based on platinum catalysts. ${ }^{15}$ Thus, an avid area of research is the development of alternative methods of $\mathrm{H}_{2}$ production using more common, cheaper alternatives. In this way, investigation of the $\mathrm{H}_{2}$ evolution reaction (HER) necessitates analysis of the key step: metal hydride formation.

The interface between two immiscible electrolyte solutions (ITIES), for example, at a waterl1,2-dichloroethane (wIDCE) interface, provides an alternative electrochemical perspective from which to investigate the HER. Different charge transfer reactions can be monitored by controlling the potential difference between the two phases. ${ }^{16}$ Employing this utility, our group has developed an alternative strategy ${ }^{17}$ to produce $\mathrm{H}_{2}$ that relies on electron reductants (e.g., metallocenes), dissolved in an organic electrolyte solution and an acidic aqueous solution. In this way, product separation is inherent within the system, which is ultimately biomimetic. Upon polarization of the interface, either via the application of an external voltage or by dissolving a common ion in both phases, protons are pumped into the organic phase. Thus, the potential-dependent proton transfer step, with corresponding metal hydride formation, can be controlled and monitored electrochemically, thus facilitating the reactions kinetic/ thermodynamic investigation. Furthermore, this methodology takes advantage of the fact that proton reduction in organic solvents, such as DCE, is thermodynamically more favorable than in aqueous media. ${ }^{17}$ Consequently, milder organic donors, with higher (more positive) redox potentials, can be effectively coupled to proton pumping across the interface to produce $\mathrm{H}_{2}$. In our recent work, we demonstrated the production of $\mathrm{H}_{2}$ by decamethylruthenocene $\left(\mathrm{Cp}_{2}^{*} \mathrm{Ru}^{(\mathrm{II})} ; \mathrm{Cp}^{*}=\mathrm{C}_{5} \mathrm{Me}_{5}\right) .{ }^{18}$ Exploration of the mechanistic pathway revealed that the reaction could produce $\mathrm{H}_{2}$ without an additional photosensitizer avoiding several electron transfer steps. Thus, coupling of the $\mathrm{Cp}_{2}^{*} \mathrm{Ru}^{\text {III }}$ photocatalytic scheme with soft interfaces represents an interesting model platform to study the photoproduction of $\mathrm{H}_{2}$ and is the major focus of this article.

In the present work, the first HER by $\mathrm{Cp}_{2}^{*} \mathrm{Ru}^{(\mathrm{II})}$ at the liquidl liquid interface is presented. The hydride formation was characterized voltammetrically and the biphasic mechanism elucidated through comparison of experimental and simulated cyclic voltammograms (CVs); the latter generated using a $1 \mathrm{D}$ geometry developed within COMSOL Multiphysics software. A modified electrochemical $(\mathrm{E})$-chemical $\left(\mathrm{C}^{\prime}\right)$, or EC' mechanism, was the primary pathway evaluated, where potentialdependent interfacial proton transfer (from $w$ to DCE) and the formation of the metal hydride within the bulk DCE phase constituted the electrochemical and chemical steps, respectively.

\section{THEORY}

2.1. Mechanism of Hydrogen Evolution at a Liquid/ Liquid Interface. At its core, the mechanism of metallocene hydride formation, as recently presented, can be regarded as an interfacial complexation reaction; whereby, the proton takes on the role of the ligand and coordinates to the metal center of $\mathrm{Cp}_{2}^{*} \mathrm{Ru}^{(\mathrm{II})}$. Interfacial complexation reactions have been widely studied $^{19,20}$ and offer insight into a possible mechanism for the ruthenocene hydride formation, ${ }^{21,22}$ either by transfer through interfacial complexation/decomplexation (TIC/TID); transfer of the proton, followed by organic phase complexation (TOC); or aqueous phase complexation, then transfer (ACT). In order to elucidate a possible reaction pathway, along with the associated kinetics/thermodynamics, a model was constructed within COMSOL Multiphysics software utilizing a simplified 1D geometry as described in detail elsewhere. ${ }^{23}$ Similar simulations have been employed to examine complex systems occurring at microelectrodes, indicating possible challenges with the use of ultramicroelectrodes, ${ }^{24}$ as well as the mechanistic elucidation and detection of short-lived radical species coupled with scanning electrochemical microscopy. ${ }^{25}$ The diffusion of chemical species within the system was defined using Fick's laws, while the electrochemical flux of ions across the ITIES was defined using the Butler-Volmer series of equations as has been described previously. ${ }^{23}$ Further simulation details, along with the terms and coefficients, have been provided in the Supporting Information (SI) and Table S1.

\section{EXPERIMENTAL SECTION}

3.1. Chemicals. All chemicals were used as received without further purification. All aqueous solutions were prepared with ultrapure water (Millipore Milli-Q, specific resistivity $18.2 \mathrm{M} \Omega \mathrm{cm}$ ). The solvents employed were 1,2-dichloroethane (DCE, $\geq 99.8 \%$, Fluka), $\alpha, \alpha, \alpha$-trifluorotoluene (TFT, $\geq 99 \%$, SigmaAldrich), hydrochloric acid ( $\mathrm{HCl}, 37 \%$, Merck), and sulfuric acid $\left(\mathrm{H}_{2} \mathrm{SO}_{4}, 98 \%\right.$, Merck). Decamethylruthenocene $\left(\mathrm{Cp}_{2}^{*} \mathrm{Ru}^{(\mathrm{II})}, 99 \%\right)$ was supplied by ABCR and stored under a nitrogen atmosphere until use. Anhydrous lithium chloride ( $\mathrm{LiCl}, \geq 99 \%)$, anhydrous sodium sulfate $\left(\mathrm{Na}_{2} \mathrm{SO}_{4}, \geq 99 \%\right)$, and tetraethylammonium chloride ( $\mathrm{TEACl}, \geq 98 \%)$ were obtained from Fluka.

Lithium tetrakis(pentafluorophenyl)borate diethyl etherate $\left(\left[\mathrm{Li}\left(\mathrm{OEt}_{2}\right)_{2}\right] \mathrm{TB}\right.$, Boulder Scientific) and bis(triphenylphosphoranylidene)ammonium chloride (BACl, $\geq 98 \%$, Aldrich) were used to prepare bis(triphenylphosphoranylidene)ammonium tetrakis(pentafluorophenyl)borate (BATB) by metathesis of equimolar solutions of $\mathrm{BACl}$ and $\left.\mathrm{Li}\left(\mathrm{OEt}_{2}\right)_{2}\right] \mathrm{TB}$ in methanol/water $(2 / 1, \mathrm{v} / \mathrm{v})$. The resulting precipitate was collected by filtration, washed, and recrystallized from acetone.

3.2. WaterIDCE, Shake-Flask Methodology. All anaerobic experiments were prepared using aqueous and organic solutions previously saturated with nitrogen and transferred to a nitrogen filled glovebox; wherein, samples were either placed in a black box for dark conditions or illuminated with whitelight using a $500 \mathrm{~W}$ xenon lamp (Oriel, Research Arc Lamp Source).

Two-phase, so-called "shake-flask", experiments were performed in septum-sealed glass vials with a solution composed of an oil (o) phase of DCE and an aqueous (w) phase whose compositions are exemplified schematically in Vial 1, below:

$\begin{gathered}2.5 \text { mM DMRc } \\ 5 \text { mM BATB } \\ \text { (DCE) }\end{gathered} \mid \begin{gathered}0.1 \mathrm{M} \mathrm{HCl} \\ 5 \mathrm{mM} \mathrm{LiTB}-\mathrm{DEE} \\ (\mathrm{w})\end{gathered}$

After combining the two phases, a magnetic stirrer was added, the vial was sealed, and then stirred for $60 \mathrm{~min}$ at ambient temperature.

One milliliter portions of the headspace gas from shake-flask vials were sampled using a lock-in syringe with a push-pull valve (SGE Analytical Sciences) and subsequently analyzed via injection into a gas chromatograph (PerkinElmer GC) equipped with a $20 \mu \mathrm{L}$ sample loop, a $5 \AA$ molecular sieves 
column, with argon used as carrier gas, and a 80/100 mesh thermal conductivity detector (TCD).

$\mathrm{UV} /$ vis spectra were recorded with an Agilent Carry 8453 photodiode array spectrophotometer employing a quartz cell with an optical path length of $1 \mathrm{~cm}$.

3.3. Electrochemical Measurements. Charge transfer reactions between wIDCE were characterized using a traditional four electrode, electrolytic cell, as described previously, , $2,26,27$ with an interfacial surface area of $\sim 1.53 \mathrm{~cm}^{2}$, and controlled through a PGSTAT 30 potentiostat (Metrohm, CH). Two platinum counter electrodes, connected to the working and counter electrode leads of the potentiostat were positioned in the aqueous and organic phases, respectively, and supplied the current. An external potential was applied by means of $\mathrm{Ag} / \mathrm{AgCl}$ reference electrodes placed in Luggin capillaries whose tapered openings were positioned proximal and on opposing sides of the ITIES. This configuration can be described through Cell 1 below:

$$
\operatorname{Ag} \operatorname{AgCl}\left|\begin{array}{c}
10 \mathrm{mM} \mathrm{LiCl} \\
1 \mathrm{mMBACl} \\
(w \approx r e f)
\end{array}\right| \begin{gathered}
5 \mathrm{mM} \mathrm{Cp}_{2}^{*} \mathrm{Ru}^{(I I)} \\
5 \mathrm{mMBATB}
\end{gathered}|| \underset{(\text { BCE })}{z \mathrm{MHCl}}|\operatorname{AsCl}| \mathrm{Ag}
$$

The concentration of $\mathrm{HCl}(z)$ was varied from 0.001 to 0.010 ,

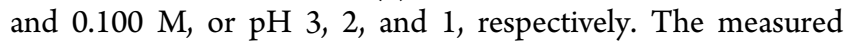
Galvani potential difference across the wIDCE interface, $\Delta_{\mathrm{o}}^{\mathrm{w}} \phi$, was calibrated relative to the formal ion transfer potential of the tetraethylammonium cation $\left(\mathrm{TEA}^{+}\right)$, taken to be $0.019 \mathrm{~V}$, $^{28}$ except for the determination of the formal ion transfer potential of the decamethylruthenocenium ion $\left(\left[\mathrm{Cp}_{2}^{*} \mathrm{Ru}^{(\mathrm{II})}\right]^{+}\right)$,

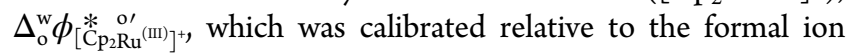
transfer potential $\left(\Delta_{\mathrm{o}}^{\mathrm{w}} \phi^{\mathrm{o} \prime}\right)$ of tetramethylammonium cation $\left(\mathrm{TMA}^{+}\right)$, taken to be $0.160 \mathrm{~V}{ }^{29}$ The half-wave ion transfer potentials $\left(\Delta_{\mathrm{o}}^{\mathrm{w}} \phi_{1 / 2}\right)$ of $\mathrm{TEA}^{+}$and $\mathrm{TMA}^{+}$were determined using cyclic voltammetry $(\mathrm{CV})$. Experiments were performed with aqueous and organic phases thoroughly degassed using nitrogen, under anaerobic conditions in a nitrogen filled glovebox, in the dark, and at an ambient temperature, unless otherwise stated.

\section{RESULTS AND DISCUSSION}

4.1. Cyclic Voltammetric Observations at wIDCE Interfaces. Figure $1 \mathrm{~A}$ depicts the $\mathrm{CVs}$ obtained at a scan rate of $0.050 \mathrm{~V} \mathrm{~s}^{-1}$ using Cell 1 at varying $\mathrm{pH}$, from 3 to 2 to 1 for the red, blue, and green traces, respectively, as well as in the absence of $\mathrm{Cp}_{2}^{*} \mathrm{Ru}^{\text {(II) }}$ (black trace) at $\mathrm{pH} 3$, which served as the blank. In the case of the blank, the potential window is limited by the transfer of protons from (w) to (o) at the positive end, and similarly chloride ion $\left(\mathrm{Cl}^{-}\right)$transfer at negative potentials.

Upon closer inspection, the blank curve, without $C p_{2}^{*} \mathrm{Ru}^{(\mathrm{II})}$, differs from the CVs obtained in the presence of $\mathrm{Cp}_{2}^{*} \mathrm{Ru}^{\text {(II) }}$ in two respects. First, at the positive end, the CV potential profile for the blank has an expected return peak at $0.413 \mathrm{~V}$, indicative of protons transferring back from (o) to (w); however, this curve feature is absent in the CVs acquired in the presence of $\mathrm{Cp}_{2}^{*} \mathrm{Ru}^{(\mathrm{II})}$ indicating irreversible proton transfer. This is in good agreement with the results of Samec et al. ${ }^{30}$ for ferrocene derivatives, along with our recent results ${ }^{23,26,31}$ using decamethylferrocene $\left(\mathrm{Cp}_{2}^{*} \mathrm{Fe}^{(\mathrm{II})}\right)$ at a wIDCE interface. For the latter, proton transfer is followed by $\left[\mathrm{Cp}_{2}^{*} \mathrm{Fe}^{(\mathrm{IV})}(\mathrm{H})\right]^{+}$formation, which subsequently reacts with dissolved $\mathrm{O}_{2}$ to generate

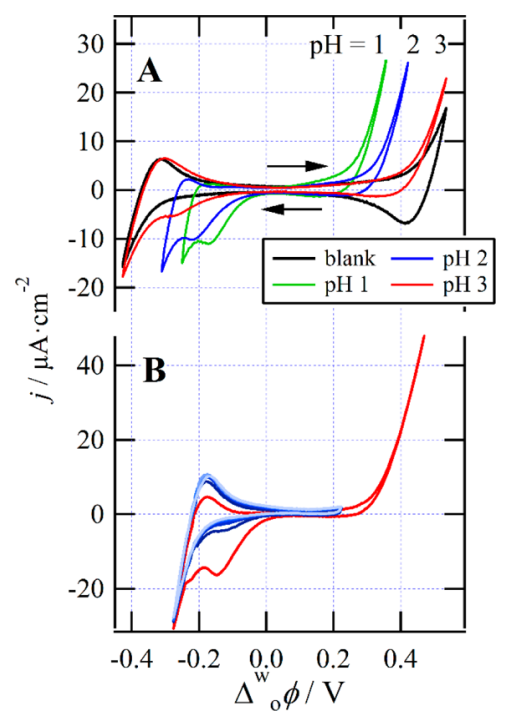

Figure 1. (A) CVs obtained using Cell 1 and varying $z$ as indicated, while the blank curve $(-)$ was acquired in the absence of $\mathrm{Cp}_{2}^{*} \mathrm{Ru}^{(\mathrm{II})}$ with $z=0.001 \mathrm{M} \mathrm{HCl}$. (B) Overlay of CVs recorded using Cell 1 with $z$ equal to $0.010 \mathrm{M} \mathrm{HCl}$ while increasing the limit of the positive potential range. All CVs were performed at a scan rate of $0.050 \mathrm{~V} \mathrm{~s}^{-1}$.

$\left[\mathrm{Cp}_{2}^{*} \mathrm{Fe}^{(\mathrm{III})}\right]^{+}$as well as $\mathrm{H}_{2} \mathrm{O}_{2}$ and $\mathrm{H}_{2} \mathrm{O}$; i.e., eliciting the oxygen reduction reaction (ORR). Therefore, for the present case, it is likely that protons are coordinating to $\mathrm{Cp}_{2}^{*} \mathrm{Ru}^{(\mathrm{II})}$ and generating $\left[\mathrm{Cp}_{2}^{*} \mathrm{Ru}^{(\mathrm{IV})}(\mathrm{H})\right]^{+}$.

Second, after addition of $\mathrm{Cp}_{2}^{*} \mathrm{Ru}^{(\mathrm{II})}$ and during the cathodic scan in Figure 1A, a peak-shaped wave emerges with a peak potential, $\Delta_{\mathrm{o}}^{\mathrm{w}} \phi_{\mathrm{p}}$ at approximately $-0.280 \mathrm{~V}$ for $\mathrm{pH} 3$. This ion transfer wave is likewise irreversible in that an analogous peak is not observed in the anodic scan. Fundamentally, this could be attributed to either transfer of a positively charged species, from (o) to (w), or that of a negatively charged species, from (w) to (o). An initial clue to the origin of this ion transfer peak was obtained when the $\mathrm{CV}$ potential range was manipulated (see Figure 1B) such that the initial CV was swept to moderate positive potentials while subsequent scans went to increasing positive potentials. The ion transfer wave at roughly $-0.280 \mathrm{~V}$ was observed to increase in cathodic current intensity concomitantly with increases in the positive potential range. Therefore, it can be concluded that there is a correlation between the occurrence of this peak, along with its intensity, and the amount of protons transferred. Indeed, after consideration of the control experiments discussed vide infra, this ion transfer wave is attributed to the transfer of $\left[\mathrm{Cp}_{2}^{*} \mathrm{Ru}^{(\mathrm{IV})}(\mathrm{H})\right]^{+}$from (o) to $(\mathrm{w})$, the rate of formation of which is intimately linked to the quantity of protons transferred from $(\mathrm{w})$ to $(\mathrm{o})$.

One alternative positively charged species that may be present in DCE is the cationic $\left[\mathrm{Cp}_{2}^{*} \mathrm{Ru}{ }^{(\mathrm{III})}\right]^{+}$species. Therefore, the latter was synthesized by electrolysis, as described previously, ${ }^{18}$ and its formal ion transfer potential $\left(\Delta_{\mathrm{o}}^{\mathrm{w}} \phi_{\left[{ }_{\left[\mathrm{C}_{2} \mathrm{Ru}^{\prime}\right.}^{*}{ }^{(\mathrm{III})}\right]^{\prime}}\right)$ determined through $\mathrm{CV}$ to be $0.005 \mathrm{~V}$ (see Cell S1 and Figure $\mathrm{S} 1$ in the SI). Owing to the disparity between this value recorded for $\left[\mathrm{Cp}_{2}^{*} \mathrm{Ru}^{(\mathrm{III})}\right]^{+}$and that found using Cell 1 , one can conclude that the transfer wave at roughly $-0.280 \mathrm{~V}$ is not owing to $\left[\mathrm{Cp}_{2}^{*} \mathrm{Ru}^{(\mathrm{III})}\right]^{+}$. Two further possibilities are the transfer of $\left[\mathrm{Cp}_{2}^{*} \mathrm{Ru}^{(\mathrm{IV})}(\mathrm{H})\right]^{+}$from $(\mathrm{o})$ to $(\mathrm{w})$, or potential interactions between $\mathrm{Cp}_{2}^{*} \mathrm{Ru}^{\text {(II) }}$ and $\mathrm{Cl}^{-}$that may facilitate $\mathrm{Cl}^{-}$ transfer from $(\mathrm{w})$ to $(\mathrm{o})$. In order to differentiate between these 
two possibilities, $\mathrm{HCl}$ was replaced by $5 \mathrm{mM}$ of $\mathrm{Li}_{2} \mathrm{SO}_{4}$, and subsequently, one drop of $0.5 \mathrm{M} \mathrm{KCl}$ solution was added (see Cell S2 and Figure S2 in the SI). In the case of Cell S2 with $\mathrm{Li}_{2} \mathrm{SO}_{4}$, the CV was not affected by the presence of $\mathrm{Cp}_{2}^{*} \mathrm{Ru}^{(\mathrm{II})}$; this indicates that $\mathrm{Li}^{+}$does not coordinate to $\mathrm{Cp}_{2}^{*} \mathrm{Ru}^{(\mathrm{II})}$ nor do protons within its hydration sphere, as was recently discovered for $\mathrm{Cp}_{2}^{*} \mathrm{Fe}^{(\mathrm{II})}{ }^{23,31}$ After addition of $\mathrm{KCl}$, the potential window response narrowed owing to the reversible $\mathrm{K}^{+}$and $\mathrm{Cl}^{-}$transfer at the positive and negative limits, respectively. No ion transfer wave was observed in the region of $-0.280 \mathrm{~V}$ and a return peak was observed in the current-potential profile at the positive potential limit; therefore, one can conclude that $\mathrm{Cl}^{-}$does not interact with $\mathrm{Cp}_{2}^{*} \mathrm{Ru}^{(\mathrm{II})}$, at least in a manner observable by $\mathrm{CV}$. However, when $\mathrm{HCl}$ (Cell 1) was replaced by $\mathrm{H}_{2} \mathrm{SO}_{4}$ (see Cell S3 and Figure S3 in the SI) the obtained CV generated a similar profile to that illustrated in Figure 1A, i.e., irreversible proton transfer at the positive potential limit, as well as an asymmetric ion transfer wave at $-0.280 \mathrm{~V}$. Therefore, proton interaction with $\mathrm{Cp}_{2}^{*} \mathrm{Ru}^{(\mathrm{II})}$, generating $\left[\mathrm{Cp}_{2}^{*} \mathrm{Ru}^{(\mathrm{IV})}(\mathrm{H})\right]^{+}$, plays a key role in the observed CVs.

To further explore the formation of $\left[\mathrm{Cp}_{2}^{*} \mathrm{Ru}^{(\mathrm{IV})}(\mathrm{H})\right]^{+}, \mathrm{CVs}$ were performed using Cell S4 and have been plotted in Figure $\mathrm{S} 4$ of the SI such that the concentration of $\mathrm{Cp}_{2}^{*} \mathrm{Ru}^{(\mathrm{II})}$ in DCE was varied, while HTB has been added to the organic phase. When the concentration of HTB is roughly equivalent to that of $\mathrm{Cp}_{2}^{*} \mathrm{Ru}^{(\mathrm{II})}(z=165 \mu \mathrm{M})$, the proton return peak is relatively unchanged relative to the blank trace (without HTB or $\mathrm{Cp}_{2}^{*} \mathrm{Ru}^{(\mathrm{II})}$ ). However, the transfer wave at $\Delta_{\mathrm{o}}^{\mathrm{w}} \phi_{\mathrm{p}} \approx-0.280 \mathrm{~V}$ is still present. Therefore, one can conclude that $\left[\mathrm{Cp}_{2}^{*} \mathrm{Ru}^{(\mathrm{IV})}(\mathrm{H})\right]^{+}$is generated in the organic phase using dissolved HTB and that one equivalent of the acid is sufficient to fully convert $\mathrm{Cp}_{2}^{*} \mathrm{Ru}^{(\mathrm{II})}$ to $\left[\mathrm{Cp}_{2}^{*} \mathrm{Ru}^{(\mathrm{IV})}(\mathrm{H})\right]^{+}$. Furthermore, as illustrated in Figure S4, the magnitude of the proton return peak decreases with increasing $\mathrm{Cp}_{2}^{*} \mathrm{Ru}^{(\mathrm{II})}$ concentration as the HTB concentration remains static. One can consider as the $\mathrm{Cp}_{2}^{*} \mathrm{Ru}^{\text {(II) }}$ concentration increases the rate of complexation increases concomitantly (more $\mathrm{Cp}_{2}^{*} \mathrm{Ru}^{\text {(II) }}$ are free to coordinate to protons) and the rate of dissociation decreases. This accounts for the decrease in magnitude of the proton return peak with a simultaneous increase in magnitude of the $\left[\mathrm{Cp}_{2}^{*} \mathrm{Ru}^{(\mathrm{IV})}(\mathrm{H})\right]^{+}$transfer wave as the concentration of $\mathrm{Cp}_{2}^{*} \mathrm{Ru}^{\text {III }}$ increases (Figure S4). However, it was not possible to study the intensity of the current for the wave relative to $\left[\mathrm{Cp}_{2}^{*} \mathrm{Ru}^{(\mathrm{IV})}(\mathrm{H})\right]^{+}$transfer quantitatively because the latter is highly sensitive to the proton concentration of the organic phase, which is not stable owing to ITIES polarization and the presence of HTB.

4.2. Shake-Flask Experiments. In order to further investigate the phenomena observed voltammetrically, shakeflask experiments were performed using the wIDCE solution composition described for Vial 1 in section 3.2. Two main conditions were varied: with/without (i) light exposure and (ii) electrochemical polarization of the wIDCE interface. In order to polarize the interface, a phase transfer catalyst was employed, as previously described, ${ }^{32-34}$ using $\mathrm{TB}^{-}$as the common ion initially dissolved in the aqueous phase. $\mathrm{TB}^{-}$spontaneously transfers from $(\mathrm{w})$ to $(\mathrm{o})$ and fixes the Galvani potential difference across the ITIES at positive values $\left(\Delta_{\mathrm{o}}^{\mathrm{w}} \phi \approx 0.50 \mathrm{~V}\right)$. Simultaneously, protons are driven to the organic phase; by which means they are available to react with $\mathrm{Cp}_{2}^{*} \mathrm{Ru}^{(\mathrm{II})}$.

Photographs taken of the reaction vial for the case where both light illumination and ITIES polarization were used are displayed in Figures $2 \mathrm{~A}-\mathrm{C}$. Once solubilized in DCE, $\mathrm{Cp}_{2}^{*} \mathrm{Ru}^{(\mathrm{II})}$ produced a clear organic phase (Figure $2 \mathrm{~A}$ ). After $1 \mathrm{~h}$
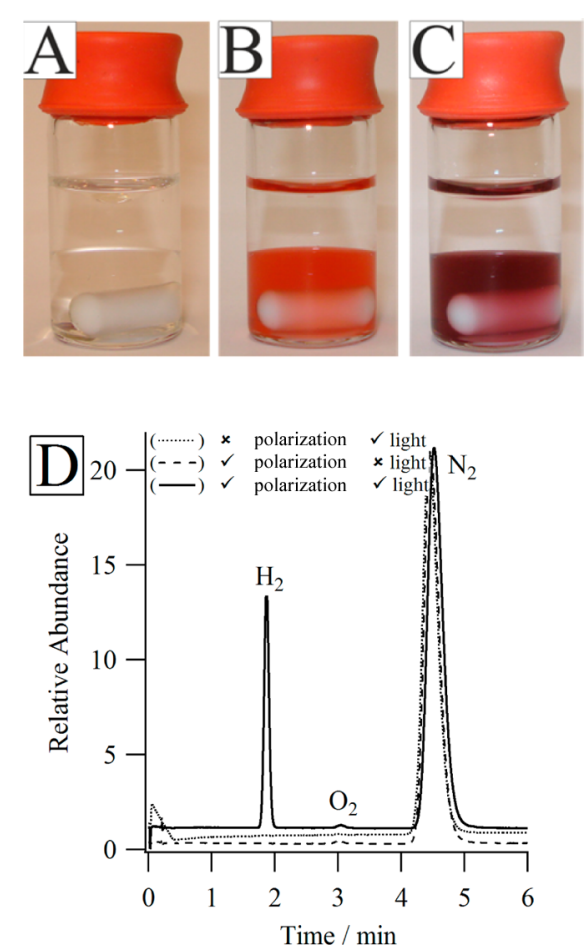

Figure 2. Gas chromatograms of the shake-flask headspace gas for experiments performed using Vial 1 (above) recorded after $60 \mathrm{~min}$ of stirring under anaerobic conditions in the dark (dashed curve), and under white-light illumination without $\left[\mathrm{Li}\left(\mathrm{OEt}_{2}\right)_{2}\right] \mathrm{TB}$ (dotted trace) and with $\left[\mathrm{Li}\left(\mathrm{OEt}_{2}\right)_{2}\right] \mathrm{TB}$ (solid line). Note that the presence of $\left[\mathrm{Li}\left(\mathrm{OEt}_{2}\right)_{2}\right] \mathrm{TB}$ indicates ITIES polarization at $\Delta_{\mathrm{o}}^{w} \phi \approx 0.5 \mathrm{~V}$.

of irradiation, the DCE phase exhibited a pink color (Figure 2B) with a strong UV/vis absorption band at $500 \mathrm{~nm}$ (see Figure S5 of the SI), which agrees well with the absorption band for $\left[\mathrm{Cp}_{2}^{*} \mathrm{Ru}^{(\mathrm{III})}\right]^{+}$as shown previously. ${ }^{18}$ If the reaction was allowed to stir for $180 \mathrm{~min}$, then the solution turned purple, which agrees with the appearance of $\left[\mathrm{Cp} * \mathrm{Ru}^{(\mathrm{IV})}\left(\mathrm{C}_{5} \mathrm{Me}_{4} \mathrm{CH}_{2}\right)\right]^{+}$(Figure $2 \mathrm{C}$ ) after prolonged photoirradiation. ${ }^{18}$ In summary, $\left[\mathrm{Cp}_{2}^{*} \mathrm{Ru}^{(\mathrm{III})}\right]^{+}$ was seen to transition from $\mathrm{Ru}$ (II) (colorless), to $\mathrm{Ru}$ (III) (pink), and finally to $\mathrm{Ru}(\mathrm{IV})$ (purple).

Additionally, after $60 \mathrm{~min}$ of stirring, the headspace gas was sampled, as described in section 3.2, and analyzed using gas chromatography; chromatograms have been plotted in Figure $2 \mathrm{D}$ for each case as indicated inset. For the case of both ITIES electrochemical polarization and light irradiation, a peak corresponding to $\mathrm{H}_{2}$ gas was observed after $\sim 2 \mathrm{~min}$; however, no $\mathrm{H}_{2}$ evolution was observed for the cases where either the phase transfer catalyst was omitted or the vial was kept in the dark. This indicates that $\mathrm{Cp}_{2}^{*} \mathrm{Ru}^{(\mathrm{II})}$ is a possible photoactive electron donor for $\mathrm{H}_{2}$ evolution under biphasic conditions and that this HER is predominately performed in the bulk organic phase; therefore, $\mathrm{Cp}_{2}^{*} \mathrm{Ru}^{\text {(II) }}$ does not undergo appreciable interfacial electron transfer to aqueous protons.

The amounts of $\mathrm{H}_{2}$ evolved were recorded as a function of time using a calibrated GC with wIDCE (red squares) as well as wltrifluorotoluene (wITFT, navy circles) liquidlliquid systems for comparison (Figure 3 ). The solution compositions were as outlined in Vial 1 but with an initial excess of $\left[\mathrm{Li}\left(\mathrm{OEt}_{2}\right)_{2}\right] \mathrm{TB}$ present in $(\mathrm{w})$ relative to $\mathrm{Cp}_{2}^{*} \mathrm{Ru}^{(\mathrm{II})}$ in (o), and therefore, an excess of protons transferred from $(\mathrm{w})$ to $(\mathrm{o})$ as tetrakis(pentafluorophenyl)borate diethyl etherate acid $\left[\mathrm{H}\left(\mathrm{OEt}_{2}\right)_{2}\right] \mathrm{TB}$. The quantity of $\mathrm{H}_{2}$ evolved was observed to reach a plateau 


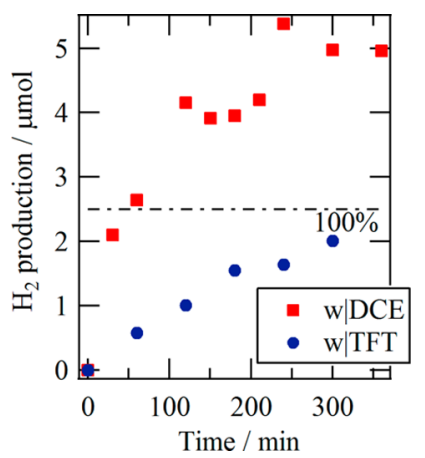

Figure 3. Plot of $\mathrm{H}_{2}$ production over time obtained by quantification of the shake-flask headspace gas, as measured by gas chromatography, for wITFT and wIDCE reactions under anaerobic conditions for experiments performed using Vial 1 (above) in the presence of excess $\left[\mathrm{Li}\left(\mathrm{OEt}_{2}\right)_{2}\right] \mathrm{TB}$.

after $180 \mathrm{~min}$ at $\sim 5.0 \mu \mathrm{mol}$. This value is twice the predicted stoichiometric amount of $\mathrm{H}_{2}$, estimated to be $2.5 \mu \mathrm{mol}$ (Figure 3, dashed line) if each $\mathrm{Cp}_{2}^{*} \mathrm{Ru}^{(\mathrm{II})}$ molecule acts as a single electron donor. Ruthenium is a well-known catalyst for hydrogenation reactions ${ }^{35-37}$ such as the Noyori asymmetric hydrogenation, ${ }^{38}$ which have become of interest in $\mathrm{CO}$ and $\mathrm{CO}_{2}$ reduction reactions to methanol. The first step in the activation of the ruthenium catalyst often involves the formation of the metal hydride, where a proton coordinates to the metal center. Organo-ruthenium complexes have also been used for $\mathrm{C}-\mathrm{H}$ bond activation, as demonstrated by the Ackermann group ${ }^{39}$ for alkyne annulations. In this way, it is possible for the ruthenium core to extract a proton from one of its ligands (e.g., a proton from one of the methyl groups on the cyclopentadienyl rings), thus providing the second equivalent of protons needed to facilitate $\mathrm{H}_{2}$ evolution. In other words, the permethylated cyclopentadienyl $\left(\mathrm{Cp}^{*}\right)$ group is converted from $\left(\eta^{5}-\mathrm{C}_{5} \mathrm{Me}_{5}\right)$ into the form of a methylenecyclotetradienyl ligand $\left(\eta^{5}-\mathrm{C}_{5} \mathrm{Me}_{4} \mathrm{CH}_{2}\right)$. Indeed, these results are in good agreement with our recent report studying the reaction mechanism of the photoproduction of $\mathrm{H}_{2}$ with $\mathrm{Cp}_{2}^{*} \mathrm{Ru}^{(\mathrm{II})}$ in a single acidified organic phase. $^{18}$

Additionally, the wIDCE biphasic system was compared to one using wITFT. TFT has been previously proposed as an alternative solvent to study charge transfer across the interface, ${ }^{40}$ as well as for $\mathrm{H}_{2}$ and $\mathrm{H}_{2} \mathrm{O}_{2}$ formation in biphasic systems, ${ }^{41}$ owing to its lower toxicity and price relative to DCE. The amount of $\mathrm{H}_{2}$ evolved over time has been plotted in Figure 3 (navy circles); however, the maximum yield approaches, but never exceeds, the quantitative yield calculated: $2.5 \mu \mathrm{mol}$. These results are similar to those made recently by Adamiak et al. ${ }^{41}$ for the spontaneous HER in the dark using $\mathrm{Cp}_{2}^{*} \mathrm{Fe}^{(\mathrm{II})}$ as the electron donor. Therein, they theorized that the low HER efficiency of the wITFT versus wIDCE interface was owing to the lower degree of $\left[\mathrm{H}\left(\mathrm{OEt}_{2}\right)_{2}\right] \mathrm{TB}$ dissociation in $\mathrm{TFT}_{;}^{41}$ this in turn limits the availability of $\mathrm{H}^{+}$. This could be the case here with $\mathrm{Cp}_{2}^{*} \mathrm{Ru}^{(\mathrm{II})}$ or, alternatively, $\pi-\pi$ interactions between the TFT molecules that can stabilize the $\left[\mathrm{Cp}_{2}^{*} \mathrm{Ru}^{(\mathrm{IV})}(\mathrm{H})\right]^{+}$species through the $\mathrm{Cp}^{*}$ ring, thereby inhibiting the intramolecular abstraction of a Cp*-proton to form $\mathrm{H}_{2}$.

4.3. Mechanistic Analysis Using Simulated Voltammetric Curves. In order to consolidate and further evaluate the voltammetric curves and shake-flask data, a theoretical model was constructed using COMSOL Multiphysics software (details in the SI and Section 2 vide supra). The experimental data leads one to conclude that proton transfer is coupled to a bulk, organic phase reaction; whereby, protons are consumed in the organic phase and unavailable to undergo ion transport back across the ITIES, effectively generating an irreversible ion transfer process. With this in mind, the proposed mechanism (Figure 4) includes a potential-dependent proton transfer step

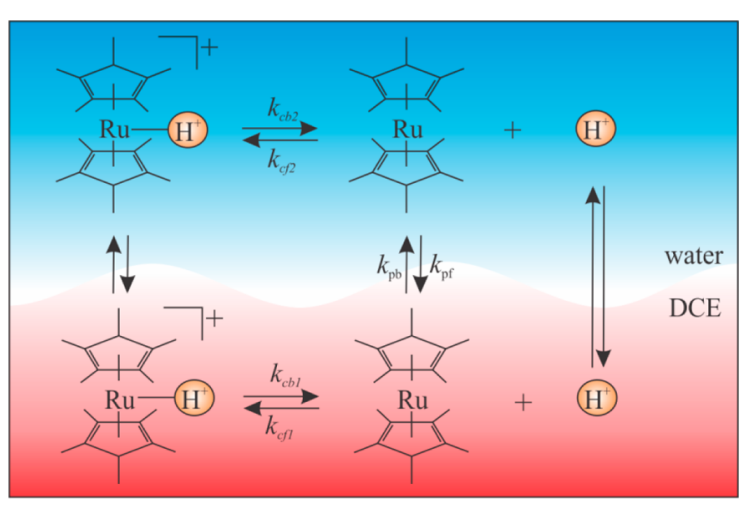

Figure 4. Biphasic decamethylruthenocene mechanism of hydride formation, present in both aqueous and organic phases, while also including potential-dependent proton and $\left[\mathrm{Cp}_{2}^{*} \mathrm{Ru}^{(\mathrm{IV})}(\mathrm{H})\right]^{+}$transfer steps as well as a potential-independent partitioning of the neutral $\mathrm{Cp}_{2}^{*} \mathrm{Ru}^{(\mathrm{II})}$ species.

followed by formation of the $\left[\mathrm{Cp}_{2}^{*} \mathrm{Ru}^{(\mathrm{IV})}(\mathrm{H})\right]^{+}$. The ion transfer wave observed experimentally, at roughly $-0.280 \mathrm{~V}$ (Figure 1B), is dependent on the concentration of protons transferred (Figure 1B); therefore, one can conclude that it is associated with $\left[\mathrm{Cp}_{2}^{*} \mathrm{Ru}^{(\mathrm{IV})}(\mathrm{H})\right]^{+}$. However, since this transfer wave is asymmetric (lacks a comparable return wave) and, as demonstrated by the shake-flask experiments for HER, is slow, relative to the time scale of the $\mathrm{CV}$ experiment, one can also conclude that the $\left[\mathrm{Cp}_{2}^{*} \mathrm{Ru}^{(\mathrm{IV})}(\mathrm{H})\right]^{+}$formed is not yet fully dissociated. Therefore, a potential-dependent $\left[\mathrm{Cp}_{2}^{*} \mathrm{Ru}^{\mathrm{IV})}(\mathrm{H})\right]^{+}$ transfer step was explored in the model (rather than a $\left[\mathrm{Cp}_{2}^{*} \mathrm{Ru}^{(\mathrm{III})}\right]^{+}$transfer step), followed by dissociation of the metal hydride in water, as the HER is not thermodynamically favored in water, and finally partitioning of the neutral $\mathrm{Cp}_{2}^{*} \mathrm{Ru}^{(\mathrm{II})}$ species back to the organic phase.

The effect of the rate of hydride formation was explored by systematically altering $k_{c f 1}$ (the rate of $\left[\mathrm{Cp}_{2}^{*} \mathrm{Ru}^{(\mathrm{IV})}(\mathrm{H})\right]^{+}$formation in the organic phase, see Figure 4), and the resultant CVs have been plotted in Figure 5; all other parameters were maintained as given in Table S1. As $k_{c f 1}$ increases from $10^{2} \mathrm{M}^{-1} \cdot \mathrm{s}^{-1}$ up to $10^{8} \mathrm{M}^{-1} \cdot \mathrm{s}^{-1}$ (Figure 5A,B) the ion transfer $\left[\mathrm{Cp}_{2}^{*} \mathrm{Ru}^{(\mathrm{IV})}(\mathrm{H})\right]^{+}$ peak increases in magnitude from 0 to $-230 \mu \mathrm{A}$. Simultaneously, the on-set potential for proton transfer decreases, and at $k_{c f 1}$ equal to $10^{8} \mathrm{M}^{-1} \cdot \mathrm{s}^{-1}$ an anodic peak was generated at $\sim 0.410 \mathrm{~V}$ (Figure 5B). This shift in the potential of proton transfer is owing to the facilitated proton transfer, where protons coordinate to the $\mathrm{Cp}_{2}^{*} \mathrm{Ru}^{(\mathrm{II})}$ metal center. Three mechanisms at the liquidlliquid interface have been recognized ${ }^{21,42}$ and are described in Section 2.1. Owing to the hydrophobicity of $\mathrm{Cp}_{2}^{*} \mathrm{Ru}^{(\mathrm{II})}$ and the dependence of the transfer wave at $-0.280 \mathrm{~V}$ on the amount of protons transferred, as demonstrated in Figure $1 \mathrm{~B}$, as well as the need for a phase transfer catalyst in the shake flask experiments (Figure 2B), a spontaneous ACT mechanism can be excluded. The effective ACT pathway included in Figure 4 is dependent on the hydride formation in the organic phase. Only then is a potential-dependent $\left[\mathrm{Cp}_{2}^{*} \mathrm{Ru}^{(\mathrm{IV})}(\mathrm{H})\right]^{+}$transfer step possible; whereby, the externally 


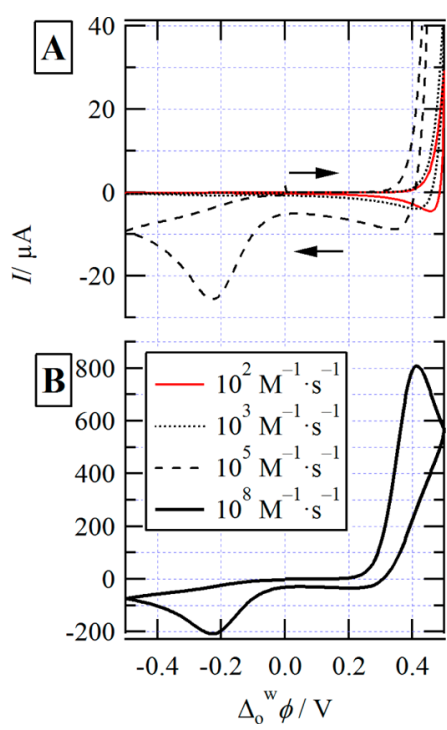

Figure 5. Simulated CVs generated using the mechanism illustrated in Figure 4 and using the parameters listed in Table S1, except that $k_{c f 1}$ has been varied as indicated and that $c_{\mathrm{H}^{+}, a q}^{*}$ was maintained at $1 \mathrm{mM}$.

applied Galvani potential difference is the driving force. For simplicity, the TIC/TID mechanism was not initially considered; however, it is a possible mechanism, but unlikely since the shake-flask experiments required electrochemical polarization in order to elicit $\mathrm{H}_{2}$ production.

In order to elucidate this point further, a two-step $\mathrm{EC}^{\prime}$ (electrochemical, E, chemical, $\mathrm{C}^{\prime}$ ) mechanism, with a potentialdependent ion transfer step $(\mathrm{E})$ of a generic species $\left(i^{z+}\right)$ followed by an irreversible complexation step $\left(\mathrm{C}^{\prime}\right.$, see equations S1 and S2 of the SI), was employed within a similar simulation geometry. In this comparatively simple system, the neutral ligand $(L)$ is considered hydrophobic and does not undergo transfer across the ITIES with the same being true of the ionligand complex $\left(i L^{z+}\right)$. The resulting CVs are given in Figure S6 with the formal ion transfer potential of $i^{z+}, \Delta_{\mathrm{o}}^{\mathrm{w}} \phi_{i^{2}}^{\mathrm{o}}$, set arbitrarily equal to $0.250 \mathrm{~V}$. As the rate of complexation increases, the half-wave potential decreases for the transfer of $i^{z+}$ and the ion transfer wave becomes asymmetric (the "cathodic" component disappears). This is in good agreement with the theory of facilitated ion transfer as has been previously established. $^{21,22,43,44}$ This also serves to further illustrate that the lack of an observable proton transfer return peak within the edge of scan profile of the CV (Figure 1A) can be satisfied by the irreversible coordination of protons to $\mathrm{Cp}_{2}^{*} \mathrm{Ru}^{(\mathrm{II})}$.

The effect of increasing $k_{c b 1}$ (the rate of $\left[\mathrm{Cp}_{2}^{*} \mathrm{Ru}^{(\mathrm{IV})}(\mathrm{H})\right]^{+}$ dissociation in the organic phase, Figure 4) was also examined, and the generated CVs have been plotted in Figure 6. With increasing $k_{c b 1}$ from 1 to $10 \mathrm{~s}^{-1}$, the concentration of $\left[\mathrm{Cp}_{2}^{*} \mathrm{Ru}^{(\mathrm{IV})}(\mathrm{H})\right]^{+}$in the vicinity of the interface decreases, the return peak for proton transfer re-emerges, and the cathodic wave for $\left[\mathrm{Cp}_{2}^{*} \mathrm{Ru}^{(\mathrm{IV})}(\mathrm{H})\right]^{+}$ transfer, (o) to (w), at $\sim 0.200 \mathrm{~V}$ decreases concomitantly. This demonstrates that the rate of complexation is high and effectively irreversible, i.e., negligible decomplexation.

Subsequently, the analogous reaction was investigated in the bulk aqueous phase by first examining the rate of decomplexation, $k_{c b 2}$ (Figure 4). Figure 7 illustrates that as $k_{c b 2}$ increases, from 50 to $10^{8} \mathrm{~s}^{-1}$, the half-wave potential of the cathodic wave shifts to more positive potentials, from -0.447 to $-0.197 \mathrm{~V}$, for the red and blue curves, respectively, such that $k_{c b 2}=10 \mathrm{~s}^{-1}$ provides a half-wave potential of $-0.280 \mathrm{~V}$.

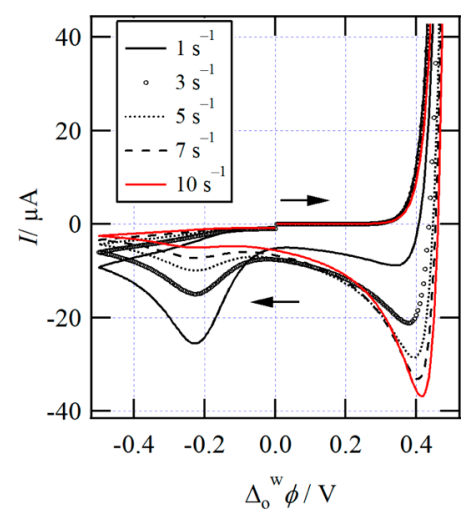

Figure 6. Simulated CVs employing the mechanism drawn in Figure 4, while $k_{c b 1}$ was varied as indicated, inset; all other parameters are the same as those listed in Table S1.
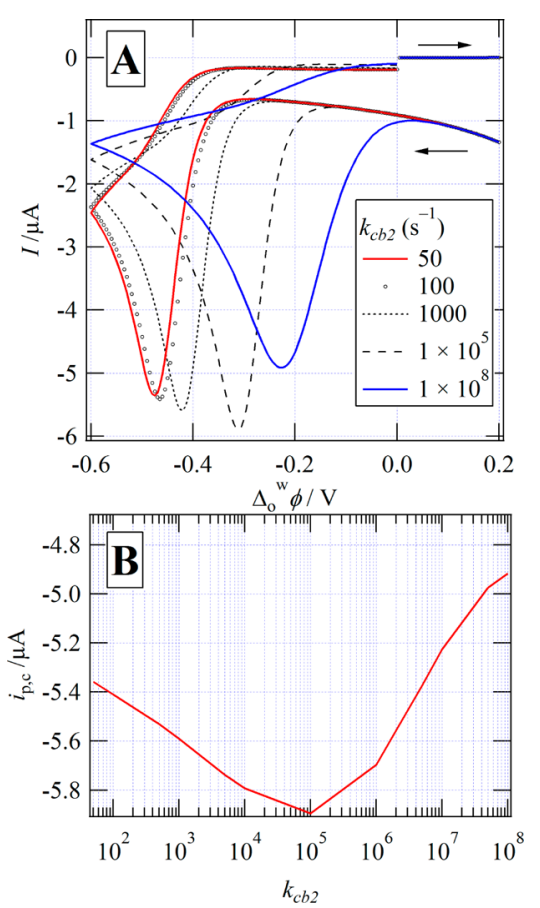

Figure 7. (A) CV traces obtained using the simulation described in Section 2. All parameters are the same as those described in Table S1 $\left(c_{\mathrm{H}^{+} a q}^{*}=1 \mathrm{mM}\right)$; however, here $k_{c b 2}$ has been altered as indicated, inset. (B) Plot of the $\left[\mathrm{Cp}_{2}^{*} \mathrm{Ru}^{(\mathrm{IV})}(\mathrm{H})\right]^{+}$transfer peak current intensity versus $k_{c b 2}$ from $[\mathrm{A}]$.

Half-wave potentials, $\Delta_{\mathrm{o}}^{\mathrm{w}} \phi_{1 / 2}$, have been calculated using the $\left[\mathrm{Cp}_{2}^{*} \mathrm{Ru}^{(\mathrm{IV})}(\mathrm{H})\right]^{+}$transfer peak potential, $\Delta_{\mathrm{o}}^{\mathrm{w}} \phi_{\mathrm{p}, \mathrm{c}}$ and the following relationship: $\Delta_{\mathrm{o}}^{\mathrm{w}} \phi_{1 / 2}=\Delta_{\mathrm{o}}^{\mathrm{w}} \phi_{\mathrm{p}}+(0.028 \mathrm{~V}) / z^{45}$ however, the ion transfer peaks in Figure 7 demonstrate a peak broadening with increasing $k_{c b 2}$. For $k_{c b 2}$ equal to 50, 100, 1000, $10^{5}$, and $10^{8} \mathrm{~s}^{-1}$, the peak width at $-4 \mu \mathrm{A}$ increases from $0.075 \mathrm{~V}$ to $0.080,0.090,0.105$, and $0.120 \mathrm{~V}$, respectively. Additionally, the peak current intensity increases negatively until $k_{c b 2}$ equals to $10^{5} \mathrm{~s}^{-1}$, after which it decreases (Figure 7B). The formal ion transfer potential for $\left[\mathrm{Cp}_{2}^{*} \mathrm{Ru}^{(\mathrm{IV})}(\mathrm{H})\right]^{+}$was approximated to be $-0.500 \mathrm{~V}$, which is just beyond the polarizable potential window (PPW). The simulated curves in Figure 7A illustrate that the transfer potential of $\left[\mathrm{Cp}_{2}^{*} \mathrm{Ru}^{(\mathrm{IV})}(\mathrm{H})\right]^{+}$is effected in a similar way by the change of the aqueous decomplexation rate as the proton transfer potential was by $k_{c f 1}$. That is, with increasing $k_{c b 2}$ the half-wave potential of $\left[\mathrm{Cp}_{2}^{*} \mathrm{Ru}^{(\mathrm{IV})}(\mathrm{H})\right]^{+}$shifts 
to more positive potentials. However, while altering $k_{c b 2}$ influences $\left[\mathrm{Cp}_{2}^{*} \mathrm{Ru}^{(\mathrm{IV})}(\mathrm{H})\right]^{+}$transfer, it does not alter the proton transfer potential; likewise, changing $k_{c f 1}$ does not impact the potential of $\left[\mathrm{Cp}_{2}^{*} \mathrm{Ru}^{(\mathrm{IV})}(\mathrm{H})\right]^{+}$transfer (Figure 6). Indeed, results obtained experimentally with Cell S4 (see SI) show that when $\mathrm{Cp}_{2}^{*} \mathrm{Ru}^{(\mathrm{II})}$ concentration, and consequently, $k_{c f 1}$ and $k_{c b 1}$, vary in the organic phase, the potential of $\left[\mathrm{Cp}_{2}^{*} \mathrm{Ru}^{(\mathrm{IV})}(\mathrm{H})\right]^{+}$ transfer remains constant. Moreover, the potential of the proton transfer appeared dependent on $k_{c f 1}$ and $k_{c b 1}$. The potentials switch to more negative values when more $\mathrm{Cp}_{2}^{*} \mathrm{Ru}^{(\mathrm{II})}$ are present because the transfer is facilitated by the proton complexation with the metallocene. However, like as was shown by simulation, the transfer potential is not expected to be dependent on $k_{c f 2}$ and $k_{c b 2}$ because the quantity of protons provided by $\left[\mathrm{Cp}_{2}^{*} \mathrm{Ru}^{(\mathrm{IV})}(\mathrm{H})\right]^{+}$is negligible compared to the amount of free protons in the aqueous phase. Therefore, the resulting simulated CVs are in good agreement with the phenomena observed experimentally (see Figure S4).

Moving forward, $k_{c f 2}$ was iteratively altered while the other rate constants were maintained (Table $\mathrm{S} 1$ in the SI); the resultant, simulated CVs have been plotted in Figure 8. As $k_{c f 2}$

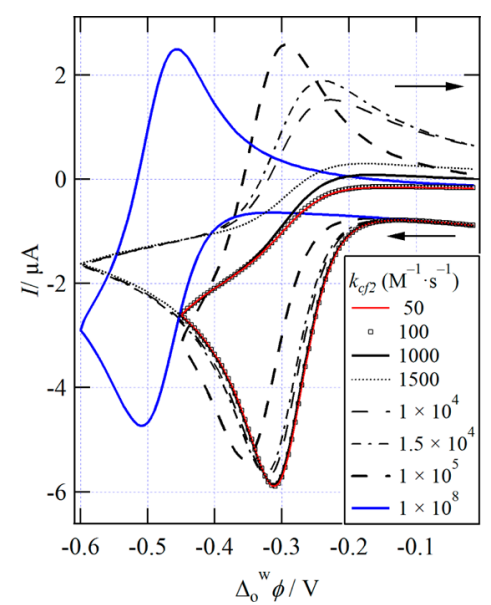

Figure 8. Simulated CV curves generated using the parameters given in Table S1, but with $k_{c f 2}$ augmented as indicated; $c_{\mathrm{H}^{+}, a q}^{*}=1 \mathrm{mM}$ and $k_{c b 2}=1 \times 10^{5} \mathrm{~s}^{-1}$.

increases, the stability of $\left[\mathrm{Cp}_{2}^{*} \mathrm{Ru}^{(\mathrm{IV})}(\mathrm{H})\right]^{+}$in the aqueous phase increases, and as $k_{c f 2}$ approaches $k_{c b 2}$, the CVs become more reversible with an anodic wave becoming visible at $1000 \mathrm{M}^{-1} \cdot \mathrm{s}^{-1}$ and continues to increase in anodic current intensity until $1 \times 10^{5} \mathrm{M}^{-1} \cdot \mathrm{s}^{-1}$. Simultaneously, the half-wave potential for $\left[\mathrm{Cp}_{2}^{*} \mathrm{Ru}^{(\mathrm{IV})}(\mathrm{H})\right]^{+}$decreased until $1 \times 10^{8} \mathrm{M}^{-1} \cdot \mathrm{s}^{-1}$, where it equals approximately the arbitrary value set in the simulation parameters.

The simulated data in Figures 7 and 8 indicate that the aqueous reaction heavily favors the dissociation of $\left[\mathrm{Cp}_{2}^{*} \mathrm{Ru}^{(\mathrm{IV})}(\mathrm{H})\right]^{+}$; therefore, based on the shift in the $\left[\mathrm{Cp}_{2}^{*} \mathrm{Ru}^{(\mathrm{IV})}(\mathrm{H})\right]^{+}$half-wave potential and the asymmetry of the anodic peak (or lack thereof) values of $k_{c f 2}$ and $k_{c b 2}$ have been estimated to be $100 \mathrm{M}^{-1} \cdot \mathrm{s}^{-1}$ and $1 \times 10^{8} \mathrm{~s}^{-1}$, respectively.

\section{CONCLUSIONS}

We have demonstrated $\mathrm{Cp}_{2}^{*} \mathrm{Ru}^{\text {(II) }}$ can act as a sacrificial electron donor to produce $\mathrm{H}_{2}$ at polarized interfaces under light illumination employing DCE or TFT solvents.

The formation of $\left[\mathrm{Cp}_{2}^{*} \mathrm{Ru}^{(\mathrm{IV})}(\mathrm{H})\right]^{+}$at the wIDCE interface was investigated through cyclic voltammetry and subsequent comparison to simulated $\mathrm{CVs}$ generated using COMSOL
Multiphysics software in order to elucidate the kinetics/ thermodynamics. The proposed pathway follows a modified EC' mechanism that involves a potential-dependent proton transfer step (E), from (w) to (o), followed by favorable $\left[\mathrm{Cp}_{2}^{*} \mathrm{Ru}^{(\mathrm{IV})}(\mathrm{H})\right]^{+}$formation in the DCE phase $\left(\mathrm{C}^{\prime}\right)$. The HER is slow, however, and on the time scale of $\mathrm{CV}$ the $\left[\mathrm{Cp}_{2}^{*} \mathrm{Ru}^{(\mathrm{IV})}(\mathrm{H})\right]^{+}$transfers as the Galvani potential difference is swept to negative potentials (an asymmetric cathodic wave was observed) and rapidly dissociates in water. This is evidenced by two curve features in the recorded CVs: an irreversible transfer wave at the limit of the PPW for protons, along with the irreversible transfer wave at roughly $-0.280 \mathrm{~V}$ that has been herein identified as $\left[\mathrm{Cp}_{2}^{*} \mathrm{Ru}^{(\mathrm{IV})}(\mathrm{H})\right]^{+}$transfer. This is the first time an irreversible ion transfer wave has been observed in relation to metallocene hydride formation at a liquidlliquid interface and is attributed to the slow rate of reaction relative to other metallocene analogues.

The shake-flask/GC experimental data corroborates that recorded using $\mathrm{CV}$, as well as the postulated mechanism, in that $\mathrm{Cp}_{2}^{*} \mathrm{Ru}^{(\mathrm{II})}$ oxidation and $\mathrm{H}_{2}$ production were only observed when both ITIES polarization and the samples were illuminated. This indicates that the $\left[\mathrm{Cp}_{2}^{*} \mathrm{Ru}^{(\mathrm{IV})}(\mathrm{H})\right]^{+}$formation is a bulk organic phase reaction and also requires the formation of a $\left(\mathrm{Cp}_{2}^{*} \mathrm{Ru}^{(\mathrm{II})}\right)^{*}$ or $\left(\left[\mathrm{Cp}_{2}^{*} \mathrm{Ru}^{(\mathrm{IV})}(\mathrm{H})\right]^{+}\right)^{*}$ excited species. The evaluation of this excited state species is underway utilizing electrogenerated chemiluminescence (ECL); however, it is beyond the scope of the present work.

Furthermore, the investigations on the effect of the rate of hydride formation explain the irreversible nature of the proton transfer when the hydride is stable and that the cathodic irreversible peak, observed in the $\mathrm{CV}$ and never seen before with other metallocenes, can be attributed to $\left[\mathrm{Cp}_{2}^{*} \mathrm{Ru}^{(\mathrm{IV})}(\mathrm{H})\right]^{+}$ transfer. The effect of the rate of hydride formation and dissociation was explored confirming that the rate of complexation is high $\left(\sim 10^{5} \mathrm{M}^{-1} \cdot \mathrm{s}^{-1}\right)$, as confirmed through the simulations, and irreversible in the DCE phase. In contrast, the absence of an associated anodic peak related to $\left[\mathrm{Cp}_{2}^{*} \mathrm{Ru}^{(\mathrm{IV})}(\mathrm{H})\right]^{+}$ transfer from $(\mathrm{w})$ to $(\mathrm{o})$, is owing to the spontaneous decomplexation of the hydride in water, which was determined to occur at a rate of $\sim 10^{5} \mathrm{~s}^{-1}$, while a rate of aqueous complexation was also estimated to be $100 \mathrm{M}^{-1} \cdot \mathrm{s}^{-1}$. Furthermore, the transfer potential of the hydride is affected by the rate of the decomplexation of the hydride in the aqueous phase; however, it does not alter the proton transfer potential. Likewise, changing the rate of formation of the hydride in DCE phase does not impact the potential transfer of $\left[\mathrm{Cp}_{2}^{*} \mathrm{Ru}^{(\mathrm{IV})}(\mathrm{H})\right]^{+}$transfer but does influence the proton transfer potential.

\section{ASSOCIATED CONTENT}

\section{Supporting Information}

The Supporting Information is available free of charge on the ACS Publications website at DOI: 10.1021/acs.jpcc.5b08148.

Additional electrolytic cells; cyclic voltammetric determination of $\left[\mathrm{Cp}_{2}^{*} \mathrm{Ru}^{(\mathrm{III})}\right]^{+}$by Cell $\mathrm{S} 1$; interaction of $\mathrm{Li}_{2} \mathrm{SO}_{4}$ and $\mathrm{KCl}$ with $\mathrm{Cp}_{2}^{*} \mathrm{Ru}^{(\mathrm{II})}$ Cell $\mathrm{S} 2$; voltammetric investigation of $\mathrm{H}_{2} \mathrm{SO}_{4}$ interaction with $\mathrm{Cp}_{2}^{*} \mathrm{Ru}^{(\mathrm{II})}$ through Cell S3; effect of $\mathrm{HTB}$ and $\mathrm{Cp}_{2}^{*} \mathrm{Ru}^{(\mathrm{II})}$ on the $\mathrm{CV}$ response using Cell S4; preparation of tetrakis(pentafluorophenyl)borate diethyl acid; UV/vis absorbance spectra for Vial 1 at $t=0$ and $60 \mathrm{~min}$; simulation details; simulation terms and coefficients; simulated 
cyclic voltammograms generated using a simplified EC' mechanism (PDF)

\section{AUTHOR INFORMATION}

\section{Corresponding Author}

*Tel: +41-21-693 3145. Fax: +41-21-693 3667. E-mail: hubert. girault@epfl.ch. Webpage: http://lepa.epfl.ch/.

\section{Notes}

The authors declare no competing financial interest.

\section{ACKNOWLEDGMENTS}

Financial support is acknowledged from the Swiss National Science Foundation, under award number 200020_152557, and the Polish-Swiss research Programm, PSB-035/2010. This publication has emanated from research by M.D.S. supported in part by a research grant from Science Foundation Ireland (SFI) under Grant Number 13/SIRG/2137.

\section{REFERENCES}

(1) Sutin, N.; Creutz, C.; Fujita, E. Photo-Induced Generation of Dihydrogen and Reduction of Carbon Dioxide Using Transition Metal Complexes. Comments Inorg. Chem. 1997, 19, 67-92.

(2) Brieger, G.; Nestrick, T. J. Catalytic transfer hydrogenation. Chem. Rev. 1974, 74, 567-580.

(3) Smith, A. M.; Whyman, R. Review of Methods for the Catalytic Hydrogenation of Carboxamides. Chem. Rev. 2014, 114, 5477-5510.

(4) Dempsey, J. L.; Brunschwig, B. S.; Winkler, J. R.; Gray, H. B. Hydrogen Evolution Catalyzed by Cobaloximes. Acc. Chem. Res. 2009, 42, 1995-2004.

(5) Wang, M.; Chen, L.; Li, X.; Sun, L. Approaches to Efficient Molecular Catalyst Systems for Photochemical $\mathrm{H}_{2}$ Production Using [FeFe]-hydrogenase Active Site Mimics. Dalton Trans. 2011, 40, $12793-12800$.

(6) Qiao, J.; Liu, Y.; Hong, F.; Zhang, J. A Review of Catalysts for the Electroreduction of Carbon Dioxide to Produce Low-carbon Fuels. Chem. Soc. Rev. 2014, 43, 631-675.

(7) Artero, V.; Chavarot-Kerlidou, M.; Fontecave, M. Angew. Chem., Int. Ed. 2011, 50, 7238-7266.

(8) Murahashi, S.-I.; Takaya, H.; Naota, T. Ruthenium Catalysis in Organic Synthesis. Pure Appl. Chem. 2002, 74, 19-24.

(9) Naota, T.; Takaya, H.; Murahashi, S.-I. Ruthenium-Catalyzed Reactions for Organic Synthesis. Chem. Rev. (Washington, DC, U. S.) 1998, 98, 2599-2660.

(10) Nalesnik, T. E.; Freudenberger, J. H.; Orchin, M. Radical Hydroformylation and Hydrogenation of Cyclopropenes with $\mathrm{HCo}-$ (CO)4 and $\mathrm{HMn}(\mathrm{CO}) 5$. J. Organomet. Chem. 1982, 236, 95-100.

(11) Du, P.; Schneider, J.; Luo, G.; Brennessel, W. W.; Eisenberg, R. Visible Light-Driven Hydrogen Production from Aqueous Protons Catalyzed by Molecular Cobaloxime Catalysts. Inorg. Chem. 2009, 48, 4952-4962.

(12) Liu, T.; DuBois, D. L.; Bullock, R. M. An Iron Complex with Pendent Amines as a Molecular Electrocatalyst for Oxidation of Hydrogen. Nat. Chem. 2013, 5, 228-233.

(13) Hoffert, M. I.; Caldeira, K.; Benford, G.; Criswell, D. R.; Green, C.; Herzog, H.; Jain, A. K.; Kheshgi, H. S.; Lackner, K. S.; Lewis, J. S.; et al. Advanced technology paths to global climate stability: Energy for a greenhouse planet. Science 2002, 298, 981-987.

(14) Perry, M. L.; Fuller, T. F. A Historical Perspective of Fuel Cell Technology in the 20th Century. J. Electrochem. Soc. 2002, 149, S59S67.

(15) Hinnemann, B.; Moses, P. G.; Bonde, J.; Jørgensen, K. P.; Nielsen, J. H.; Horch, S.; Chorkendorff, I.; Nørskov, J. K. Biomimetic Hydrogen Evolution: $\mathrm{MoS}_{2}$ Nanoparticles as Catalyst for Hydrogen Evolution. J. Am. Chem. Soc. 2005, 127, 5308-5309.

(16) Hung, L. Q. Electrochemical Properties of the Interface between Two Immiscible Electrolyte Solutions: Part I. Equilibrium situation and galvani potential difference. J. Electroanal. Chem. Interfacial Electrochem. 1980, 115, 159-174.

(17) Méndez, M. A.; Partovi-Nia, R.; Hatay, I.; Su, B.; Ge, P. Y.; Olaya, A.; Younan, N.; Hojeij, M.; Girault, H. H. Molecular Electrocatalysis at Soft Interfaces. Phys. Chem. Chem. Phys. 2010, 12, 15163-15171.

(18) Rivier, L.; Vannay, L.; Méndez, M. A.; Peljo, P.; Scanlon, M. D.; Corminboeuf, C.; Girault, H. H. Photo-generation of Hydrogen by Decamethylruthenocene in Acidified Organic Media. In publication.

(19) Stockmann, T. J.; Zhang, J.; Montgomery, A.-M.; Ding, Z. Electrochemical Assessment of Water'Ionic Liquid Biphasic Systems Towards Cesium Extraction from Nuclear Waste. Anal. Chim. Acta 2014, 821, 41-47.

(20) Nestor, U.; Wen, H.; Girma, G.; Mei, Z.; Fei, W.; Yang, Y.; Zhang, C.; Zhan, D. Facilitated $\mathrm{Li}^{+}$Ion Transfer Across the Water/1,2dichloroethane Interface by the Solvation Effect. Chem. Commun. 2014, 50, 1015-1017.

(21) Peljo, P.; Girault, H. H. In Encyclopedia of Analytical Chemistry; John Wiley \& Sons, Ltd: New York, 2012.

(22) Samec, Z.; Langmaier, J.; Kakiuchi, T. Charge-transfer Processes at the Interface between Hydrophobic Ionic Liquid and Water. Pure Appl. Chem. 2009, 81, 1473-1488.

(23) Deng, H.; Stockmann, T. J.; Peljo, P.; Opallo, M.; Girault, H. H. Electrochemical Oxygen Reduction at Soft Interfaces Catalyzed by the Transfer of Hydrated Lithium Cations. J. Electroanal. Chem. 2014, 731, $28-35$.

(24) Lin, C.; Compton, R. G. Voltammetric Mechanistic Characterisation of Electrode Reactions: Distinguishing between Chemical Instability and Fast Product Diffusion. J. Electroanal. Chem. 2015, 743, 86-92.

(25) Cao, F.; Kim, J.; Bard, A. J. Detection of the Short-Lived Cation Radical Intermediate in the Electrochemical Oxidation of $\mathrm{N}, \mathrm{N}$ Dimethylaniline by Scanning Electrochemical Microscopy. J. Am. Chem. Soc. 2014, 136, 18163-18169.

(26) Stockmann, T. J.; Deng, H.; Peljo, P.; Kontturi, K.; Opallo, M.; Girault, H. H. Mechanism of Oxygen Reduction by Metallocenes near Liquid'Liquid Interfaces. J. Electroanal. Chem. 2014, 729, 43-52.

(27) Ge, P.; Todorova, T. K.; Patir, I. H.; Olaya, A. J.; Vrubel, H.; Mendez, M.; Hu, X.; Corminoboeuf, C.; Girault, H. H. Biphasic Water Splitting by Osmocene. Proc. Natl. Acad. Sci. U. S. A. 2012, 109, 11558.

(28) Wandlowski, T.; Mareček, V.; Samec, Z. Galvani Potential Scales for Water-Nitrobenzene and Water-1,2-dichloroethane Interfaces. Electrochim. Acta 1990, 35, 1173-1175.

(29) Sabela, A.; Mareček, V.; Samec, Z.; Fuoco, R. Standard Gibbs Energies of Transfer of Univalent Ions from Water to 1,2dichloroethane. Electrochim. Acta 1992, 37, 231-235.

(30) Trojánek, A.; Langmaier, J.; Samec, Z. Thermodynamic Driving Force Effects in the Oxygen Reduction Catalyzed by a metal-free Porphyrin. Electrochim. Acta 2012, 82, 457-462.

(31) Deng, H.; Peljo, P.; Stockmann, T. J.; Qiao, L.; Vainikka, T.; Kontturi, K.; Opallo, M.; Girault, H. H. Surprising Acidity of Hydrated Lithium Cations in Organic Solvents. Chem. Commun. 2014, 50, $5554-5557$.

(32) Hatay, I.; Ge, P. Y.; Vrubel, H.; Hu, X.; Girault, H. H. Hydrogen Evolution at Polarised Liquid/Liquid Interfaces Catalyzed by Molybdenum Disulfide. Energy Environ. Sci. 2011, 4, 4246-4251.

(33) Ge, P.; Todorova, T. K.; Patir, I. H.; Olaya, A. J.; Vrubel, H.; Mendez, M.; Hu, X.; Corminboeuf, C.; Girault, H. H. Biphasic Water Splitting by Osmocene. Proc. Natl. Acad. Sci. U. S. A. 2012, 109, 11558-11563.

(34) Ge, P.; Olaya, A. J.; Scanlon, M. D.; Hatay Patir, I.; Vrubel, H.; Girault, H. H. Photoinduced Biphasic Hydrogen Evolution: Decamethylosmocene as a Light-Driven Electron Donor. ChemPhysChem 2013, 14, 2308-2316.

(35) Takahashi, K.; Nozaki, K. Ruthenium Catalyzed Hydrogenation of Aldehyde with Synthesis Gas. Org. Lett. 2014, 16, 5846-5849.

(36) vom Stein, T.; Meuresch, M.; Limper, D.; Schmitz, M.; Hölscher, M.; Coetzee, J.; Cole-Hamilton, D. J.; Klankermayer, J.; Leitner.; et al. Versatile Catalytic Hydrogenation of Carboxylic and 
Carbonic Acid Derivatives using a Ru-Triphos Complex: Molecular Control over Selectivity and Substrate Scope. J. Am. Chem. Soc. 2014, 136, 13217-13225.

(37) Rezayee, N. M.; Huff, C. A.; Sanford, M. S. Tandem Amine and Ruthenium-Catalyzed Hydrogenation of $\mathrm{CO}_{2}$ to Methanol. J. Am. Chem. Soc. 2015, 137, 1028-1031.

(38) Ohkuma, T.; Koizumi, M.; Ikehira, H.; Yokozawa, T.; Noyori, R. Selective Hydrogenation of Benzophenones to Benzhydrols. Asymmetric Synthesis of Unsymmetrical Diarylmethanols. Org. Lett. 2000, 2, 659-662.

(39) Ackermann, L. Carboxylate-Assisted Ruthenium-Catalyzed Alkyne Annulations by $\mathrm{C}-\mathrm{H} / \mathrm{Het}-\mathrm{H}$ Bond Functionalizations. Acc. Chem. Res. 2014, 47, 281-295.

(40) Olaya, A. J.; Ge, P.; Girault, H. H. Ion transfer across the water'trifluorotoluene interface. Electrochem. Commun. 2012, 19, 101104.

(41) Adamiak, W.; Jedraszko, J.; Krysiak, O.; Nogala, W.; HidalgoAcosta, J. C.; Girault, H. H.; Opallo, M. Hydrogen and Hydrogen Peroxide Formation in Trifluorotoluene-Water Biphasic Systems. J. Phys. Chem. C 2014, 118, 23154-23161.

(42) Liu, S.; Li, Q.; Shao, Y. Electrochemistry at micro- and nanoscopic liquid/liquid interfaces. Chem. Soc. Rev. 2011, 40, 22362253.

(43) Reymond, F.; Lagger, G.; Carrupt, P.-A.; Girault, H. H. Facilitated Ion Transfer Reactions across Oil'Water Interfaces. Part II. Use of the Convoluted Current for the Calculation of the Association Constants and for an Amperometric Determination of the Stoichiometry of MLjz+ Complexes. J. Electroanal. Chem. 1998, 451, $59-76$.

(44) Girault, H. In Electroanalytical Chemistry; Bard, A. J., Zoski, C. G., Eds.; CRC Press: Boca Raton, FL, 2010; pp 1-104.

(45) Bard, A. J.; Faulkner, L. R. Electrochemical Methods: Fundamentals and Applications, 2nd ed.; John Wiley: New York, 2001. 